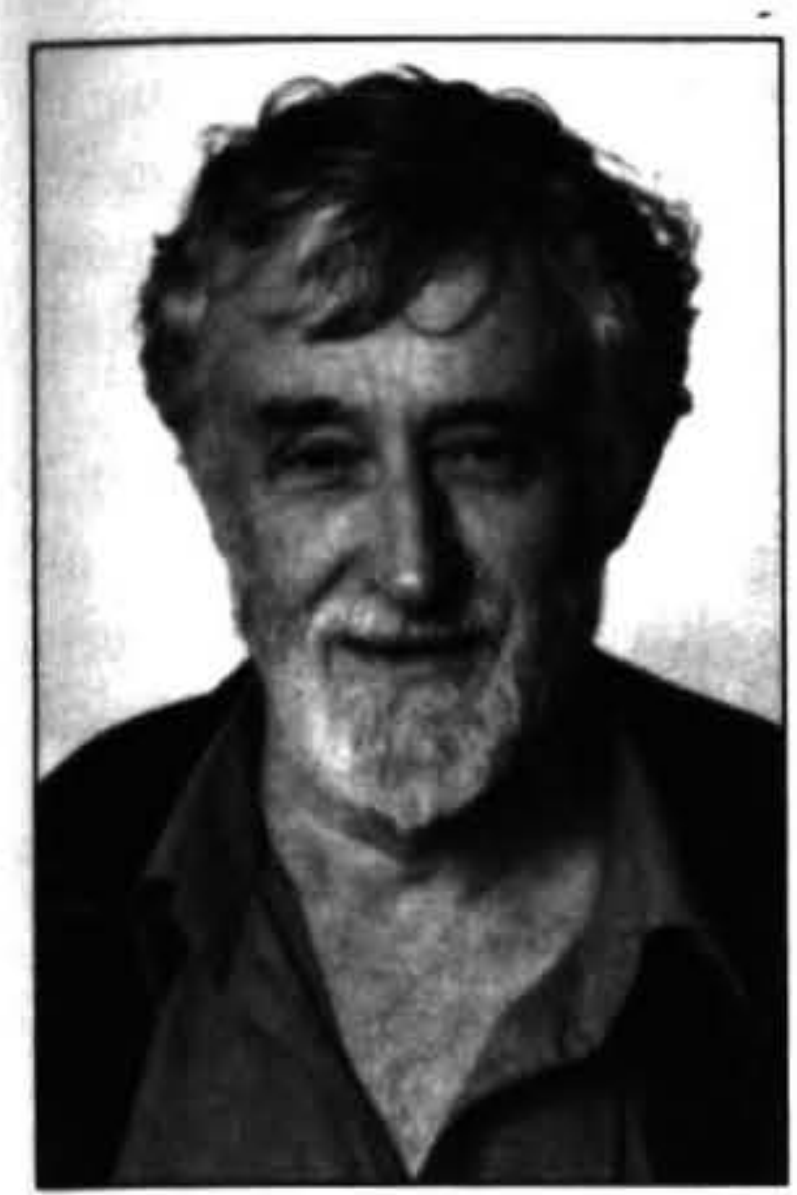

\title{
NEW TECHNOLOGY AND THE QUALITY OF WORKING LIFE IN NEW ZEALAND
}

\author{
Chris Hector \\ Waikato Management School, \\ University of Waikato, Hamilton
}

\begin{abstract}
The Waikato Management School has a FoRST contract to investigate a wide range of social and economic effects of new technology. In order to assess the impact of new technology on the quality of working life a postal questionnaire was distributed to 1800 adults selected at random across the whole of New Zealand. The present findings are preliminary, as only 274 usable responses have been received by Conference time, and they are continuing to arrive. The overwhelming majority of respondents (some $83 \%$ ) say they are generally satisfied with their paid jobs, despite more than $70 \%$ reporting that pressure has increased. Those workers who have been affected by technological change are substantially more likely to say that their work is now more interesting, in addition to being more often among the better paid.
\end{abstract}

\section{Introduction}

The present study is one part of a major FoRST contract, in which a number of staff from the Waikato Management School are investigating the uptake of new technology in New Zealand, including its social and economic effects in a variety of dimensions. A number of quantitative studies have already been undertaken, establishing that new technology is associated with wider wage dispersion and increased returns to education, with a particular trend toward fewer employment opportunities for less-educated workers in those industries which are experiencing more rapid uptake of new technologies (Hector, 2003; 2004; Hector and Gibson, 2006).

The present phase is an attempt to add a qualitative perspective to understanding the effects of new technology. It is now widely recognized that work is not only necessary for income, but is also a significant component of a person's sense of well-being (Lane, 2000). Humans are "deeply social beings" (Layard, 2006) for whom a working life gives a sense of purpose and a sense of belonging (Freeman and Soete, 1994: Phelps, 1997), and involuntary unemployment is particularly stressful and bad for health (Layard, Nickell and Jackman, 1991; Clark and Oswald, 1994).

The world of work has been changing rapidly, both in New Zealand (Spoonley, 2004) and generally in the western world (Pryor and Schaffer, 1999). The mid 20 century Fordist systems, with large, hierarchical industrial operations, are beginning to look like a phase which has largely passed, and it seems increasingly likely that the future of work will see a much greater variety of employment arrangements, including more casual and non-standard employment. At the same time the developed countries have experienced the extensive adoption of new technologies, especially Information and Communications Technologies (ICT), but it is not clear how this is connected to changes in employment and especially to the quality of work.

A questionnaire was distributed to 1800 adult New Zealanders, seeking to reveal two things. Firstly it was hoped to establish the extent to which working people were generally satisfied with the quality of their working lives, and the extent to which this had changed over recent years. Is the world of work becoming more (or less) interesting? Is it becoming more (or less) rewarding, in the psychological sense as well as in terms of remuneration and advancement opportunities?

Secondly, the questionnaire asked a range of questions about the uptake of new technology in the workplace, with a special interest in the extent to which jobs were now perceived as being more or less satisfactory as a result. It is hoped that taken in conjunction, the answers to these two sets of questions will reveal whether new technology is contributing to an improvement or a decline in the quality of working lives.

\section{The Questionnaire}

A questionnaire was distributed by mail to 1800 people randomly selected from the electoral rolls. This gave good geographic coverage of the adult population, but is skewed toward older and more established people because of the tendency for people to move more often when younger. As at of November 2006575 questionnaires had been returned, but only 274 returns were usable. More than 200 had come back gone no 
address' and nearly 100 were from people who refused to complete them, usually because they were long retired.

The questionnaire asked 62 questions:

- 14 on job satisfaction

- 12 on workplace organization

- 5 on the extent of recent ICT-adoption

- 10 on perceived effects of ICT-adoption

- 21 on demographics, such as age, sex, marital status, local government region of residence, etc.

All respondents were asked to complete the first two sections and the demographic section, so that general workplace satisfaction could be judged irrespective of whether there their job had experienced any technological change.

\section{Preliminary Findings}

Almost all questions elicited answers on a 7 point scale, where 1 is very dissatisfied. 4 is neutral and 7 is very satisfied, etc. Most workers $(83 \%)$ were generally satisfied with the quality of their working lives scoring 5 or more. $56 \%$ reported that their work has become more interesting, and about half $(49 \%)$ said they felt more valued at work.

While only half felt more valued than previously, those workers who feel more valued almost invariably said they enjoyed a good sense of satisfaction with their working lives. There is also a very strong correlation between feeling valued and finding work interesting: $70^{\circ}$ of those who say their work is interesting are also those who feel they are more valued.

\section{Differences When Workplace has Adopted New Technologi}

Of the 274 responses, $202\left(74^{\circ}\right.$ ) reported new technology in the last 5 years, but only $163\left(59^{\circ}\right)$ said new technology had changed workplace practices

From the additional explanations provided it was clear that in a number of cases the technological change was relatively slight, such as gaining access to email. The $59^{\circ} \%$ of respondents who reported significant changes to workplace practices would therefore appear to be a more interesting subset in the context of technology affecting the quality of working life.

In terms of overall job satisfaction there is scarcely any difference between the responses of workers facing technological change and those who do not. The overall response was $83 \%$ generally satisfied (scoring 5 or more), and among those in more technologized industries the figure was only fractionally higher at $83.6 \%$.

However of the 163 workers experiencing significant technological change $53 \%$ feel more valued, as compared with only $42 \%$ of those who are not in workplaces where new technology has brought much change. Also, of those in the more technological workplaces $63 \%$ say they now find work more interesting, as compared with only $47^{\circ} \%$ of the workers in the unchanging workplaces. Thus it seems that new technology is taking over the more routine tasks, and workplaces which are moving with new technology have advantages for their workers in terms of work content.

Two other trends are emerging, even at an early stage of the analysis. One is a strong positive correlation between education level and these workplaces which are changing. Many international studies have found that better levels of education have a particular advantage at times of change, since better educated workers appear to be more adaptable (Caselli, 1999; Psacharopoulos and Patrinos, 2004). Higher returns to education have previously been found for industries with greater expenditure on computing inputs (Hector, 2004) for example, suggesting that the better educated workers have an advantage in those industries. It is also expected that those workplaces which have more educated workers are changing more quickly.

Secondly, technological change is strongly correlated with a greater proportion of high wage workers. This is fully to be expected, since the last twenty years have seen increasing returns to education, and workplaces which require better educated workers naturally also pay better wages.

\section{Future Research}

With responses continuing to arrive through November, this is necessarily a report on work which is still at a very early stage. For one thing the findings should be considerably more robust when all the responses have been received. Also the large number of questions allows for a very large number of potential cross-tabulations, but it is important to have significant numbers in each subgroup if the findings are to be reliable.

It is hoped that at least 400 usable responses will ultimately be received. This should allow a variety of further questions to be pursued with reasonable confidence, including:

- Patterns by gender and by age cohorts

- Casualisation of work and working from home

- Work-life balance

- The extent to which workers feel they are more closely monitored, have more autonomy, etc.

There is a distinct bias in the responses toward workers who are older than is typical of the workforce, but the age patterns of the workforee will shortly be available from the 2006 Census, which will allow reweighting of the results to give a more accurate picture. A full report will be published in 2007 when all the potentially interesting relationships have been explored.

\section{References}

Blanchflower, D. G., and Oswald, A. J. (2000). The rising well-being of the young. In Blanchflower, 
D.G. and Freeman, R.B. (eds.), Youth Employment and Joblessness in Advanced Countries. Chicago: University of Chicago Press.

Caselli, F. (1999). Technological revolutions. American Economic Review, 89(1), 78-102.

Clark, A., and Oswald, A. J. (1994). Unhappiness and unemployment. Economic Journal, 104(424), 648-659.

Feather, N. T. (1997). Economic deprivation and the psychological impact of unemployment. Australian Psychologist, 32, 37-45.

Freeman, C., and Soete, L. (1994). Work for All or Mass Unemployment? Computerized Technical Change into the Twenty-first Century. London: Pinter.

Hector, C. (2003). Information technology use and employment change in New Zealand industries. New Zealand Journal of Industrial Relations. 28(3), 212-228.

Hector, C. (2004). The use of new technology and rising inequality in New Zealand : Evidence from unit record data. Paper presented at the Labour. Employment and Work in New Zealand (LEWII) Conference, Wellington: Victoria University of Wellington.

Hector, C., and Gibson, J. (2006). The uptake of new technology in New Zealand, and its impact on the distribution of wages. Paper presented at the New Zealand Association of Economists. Wellington.

Lane, R.E. (2000). The Loss of Happiness in Market Democracies. New Haven: Yale University Press.

Layard, R., Nickell, S., and Jackman, R. (1991). Unemployment : Macroeconomic Performance and the Labour Market. Oxford: Oxford University Press.
Layard, R. (2006). Happiness: Lessons from a New Science. London: Penguin.

Martin, J. (1994). The extent of high unemployment in OECD countries. Paper presented at the Reducing Unemployment Symposium, Jackson Hole, Wyoming.

Oswald, A.J. (1997). Happiness and economic perfomance. Economic Journal, 107(445), 18151831.

Phelps, E.S. (1997). Rewarding Work : How to Restore Participation and Self-Support to Free Enterprise. Cambridge, MA: Harvard University Press.

Pryor, F.L., and Schaffer, D.L. (1999). Who's Not Working and Why: Employment, Cognitive Skills, Wages, and the Changing U.S. Labor Market. Cambridge: Cambridge University Press.

Psacharopoulos, G., and Patrinos, H.A. (2004). Returns to investment in education: A further update. Education Economics, 12(2), 111-134.

Spoonley, P., and Davidson, C. (2004). The changing world of work. In Spoonley, P., Dupuis, A. and de Bruin, A. (Eds.), Work and Working in Twenty-first Century New Zealand. Palmerston North: Dunmore Press.

Winkelmann, L., and Winkelmann, R. (1998). Why are the unemployed so unhappy? Evidence from panel data. Economica, 65(257), 1-15.
Author
Chris Hector
Research Assistant
School of Management
University of Waikato
Private Bag 3105
Hamilton
chector@mngt.waikato.ac.nz 